УДК 352/354-043.5(477)

DOI https://doi.org/10.51989/NUL.2021.6.16

\title{
ОКРЕМІ АСПЕКТИ ВИЗНАЧЕННЯ АДМІНІСТРАТИВНО-ПРАВОВОГО СТАТУСУ ОРГАНІВ ТА ОСІБ, УПОВНОВАЖЕНИХ НА ПРИМУСОВЕ ВИКОНАННЯ СУДОВИХ РІШЕНЬ
}

\section{Мороз Віта Петрівна,}

ORCID: 0000-0003-4433-3731

доктор юридичних наук, доцент, доцент кафедри адміністративного права, процесу та адміністративної діяльності Дніпропетровського державного університету внутрішніх справ

3-поміж правових проблем, які зумовлюють неефективність виконавчого провадження в Україні, незважаючи на реформування та суттєве оновлення законодавства й упровадження змішаної системи виконавчого провадження, не останнє місце посіли недосконалість правового врегулювання адміністративно-правового статусу органів та осіб, які здійснюють примусове виконання судових рішень і рішень інших органів, неврахування норм законодавства ЄС при розробленні й нормативному закріпленні принципів діяльності таких органів та осіб, установлення майже однакових вимог до адміністративної правосуб'єктності державних і приватних виконавців, закріплення більш суворої відповідальності для державних виконавців як осіб, що здійснюють примусове виконання судових рішень і рішень інших органів, ніж для приватних виконавців тощо. Основним суб'єктом виконання рішень є державні виконавці. Вони мають статус державних службовців, від імені держави виконують функції з примусового виконання рішень публічних органів управління. 3 метою забезпечення успішного виконання цих завдань докорінного поліпшення потребують не лише форми й методи діяльності державних виконавців, а і якісний підхід до визначення адміністративно-правового статусу зазначених суб'єктів. З'ясовано, що вимог щодо високих особистих і ділових якостей до осіб приватних виконавців законодавець не встановлює, що є суттєвою прогалиною сучасного законодавства. Запровадження інституту приватного виконавця в Україні пройшло тривалий шлях, аргументи, що обґрунтовують компетентність державних виконавців порівняно з приватними виконавцями $\epsilon$ встановленими відповідно до вимог законодавства, однак проблемні аспекти $\epsilon$ відкритими й потребують удосконалення. Зроблено висновок, що адміністративно-правовий статус і діяльність органів та осіб, уповноважених на виконання судових рішень, вимагають поступового перегляду законодавчої бази для визначення регуляторних і наглядових функцій держави. Загальними вимогами, яка висуваються до особи як державного, так і приватного виконавця, є громадянство України; вища юридична освіта за ступенем «магістр»; здатність за своїми особистими й діловими якостями здійснювати повноваження державного виконавця.

Ключові слова: органи державної влади, державні службовці, посадові особи, виконання судових рішень, суб'єкти виконання рішень.

\section{Moroz Vita. Certain aspects of determining the administrative and legal status of bodies and persons authorized to enforcement of judicial decisions}

Among the legal problems that cause inefficiency of enforcement proceedings in Ukraine, despite the reform and significant updating of legislation and the introduction of a mixed system of enforcement proceedings, not least was the imperfection of the legal regulation of administrative and legal status of bodies and persons enforcing court decisions and decisions of other bodies, failure to take into account EU legislation in the development and regulation of the principles of such bodies and persons, establishing almost equal requirements for administrative legal personality of public and private executors, stricter liability for state executors as enforcers and decisions of bodies other than private performers, etc. The main subjects of execution of decisions are state executors. They have the status of civil servants, and on behalf of the state perform the functions of enforcement of decisions of public authorities. In order to ensure the successful implementation of these tasks, radical improvement is needed not only in the forms and methods of state executors, but also a quality approach to determining the administrative and legal status of these entities. It was found that the legislator does not set requirements 
for high personal and business qualities for private performers, which is a significant gap in modern legislation. The introduction of the institution of private performers in Ukraine has come a long way, the arguments justifying the competence of public performers compared to private performers are established in accordance with the law, but problematic aspects are open and need to be improved. It is concluded that the administrative and legal status and activities of bodies and persons authorized to enforce court decisions require a gradual revision of the legal framework to determine the regulatory and supervisory functions of the state. The general requirements for a person of both public and private performance are: citizenship of Ukraine; higher legal education with a master's degree; ability to exercise the powers of a state executor according to his personal and business qualities.

Key words: public authorities, civil servants, officials, execution of court decisions, subjects of execution of decisions.

Актуальність теми. Як неодноразово зазначав у рішеннях Європейський суд з прав людини, виконання рішення, винесеного будь-яким судом, має розглядатися як невід'ємна частина «судового процесу» для реалізації ст. 6 Європейської конвенції з прав людини, що передбачає виконання судових рішень, які в державах, що поважають принцип верховенства права, не можуть залишатися невиконаними [1]. Основним суб'єктом виконання рішень $\epsilon$ державні виконавці. Вони мають статус державних службовців, від імені держави виконують функції з примусового виконання рішень публічних органів управління.

На думку А. Авторгова, саме реалізація адміністративно-правового статусу державного виконавця дає можливість зміцнити законність, правову культуру державного виконавця за рахунок удосконалення підходів до організації діяльності цього суб'єкта, зокрема у взаємодії з громадянами, зміцнення державної та службової дисципліни, посилення контролю й відповідальності за неналежне виконання службових обов'язків, зокрема за бездіяльність, зволікання в реалізації виконавчого провадження щодо виконання примусового рішення [1].

Розкриваючи питання адміністративно-правового статусу, ми зосереджуємо увагу на адміністративно-правовому статусі органу державної влади, оскільки дослідження присвячено адміністративно-правовому забезпеченню примусового виконання судових рішень, де державна виконавча служба $€$ основним суб'єктом, що забезпечує виконання судового рішення, залучаючи інші уповноважені органи - органи Національної поліції, органи казначейства тощо. Однак акцен- туємо увагу й на тому, що не тільки державні органи уповноважені забезпечувати примусове виконання судового рішення. Відповідно до Закону України «Про органи та осіб уповноважені до виконання судових рішень», до них віднесено й приватних виконавців [2].

Що стосується законодавчого регламентування, то це питання регулюється такими нормативно-правовими документами, як Закон України «Про органи та осіб, які здійснюють примусове виконання судових рішень і рішень інших органів», Закон України «Про виконавче провадження», Закон України «Про виконання рішень та застосування практики Європейського суду з прав людини», Закон України «Про гарантії держави щодо виконання судових рішень», Інструкція з організації примусового виконання рішень, затверджена Наказом Міністерства юстиції України від 02.04.2012 № 512/5, Наказ Міністерства юстиції України «Про затвердження Положення про автоматизовану систему виконавчого провадження» від 05.08.2016 № 2432/5, Наказ Міністерства юстиції України «Про затвердження Порядку реалізації арештованого майна» від 29.09.2016 № 2831/5.

Стан дослідження. Зазначимо, що питанню адміністративно-правового статусу органів, уповноважених на виконання судових рішень, у працях приділяли увагу такі вчені, як А. Авер'янов, $€$. Гришко, Л. Крупнова, П. Макушев, А. Педан, А. П'ятницький, I. Француз та інші, однак у наукових дослідженнях вони висвітлювали різні теоретико-правові аспекти, напрями вдосконалення законодавчої бази й покращення практичного складника у сфері дослідження примусового виконання судових рішень. Разом із 
тим це питання $є$ надзвичайно широким і багатовекторним як із теоретичної точки зору, так і з практичного складника. Тому ми приділили окрему увагу дослідженню робіт правознавців, що вивчали тематику примусового виконання судових рішень, і в дослідженні розкриємо ті питання, які $\epsilon$ актуальними.

Метою статті $\epsilon$ узагальнити теоретичні напрацювання стосовно дослідження окремих аспектів адміністративно-правового статусу органів та осіб, уповноважених на примусове виконання судових рішень.

Виклад основного матеріалу. На початку дослідження вважаємо за необхідне зазначити, що адміністративно-правовий статус має включати як права, обов'язки, повноваження, через які вони реалізують норми права, так і юридичну відповідальність як засіб припинення та виховання в дусі додержання закону у сфері відносин, яку вона охоплює.

Так, наприклад, Т. Коломоєць зазначає, що поняття «адміністративно-правовий статус» становить сукупність суб'єктивних прав та обов'язків, закріплених нормами адміністративного права за певним органом. Водночас обов'язковою ознакою $\epsilon$ набуття суб'єктами адміністративно-правового статусу конкретних суб'єктивних прав та обов'язків, що реалізуються в рамках адміністративних правовідносин [3].

О. Якімов, Д. Овсянко із цього приводу висловлюють позицію, що адміністративно-правовий статус органу виконавчої влади включає компетенцію, правозастосування, юридичну відповідальність, а також нормативно-визначений порядок створення [4].

Частково ми погоджуємося з позицією зазначених вище науковців, оскільки адміністративно-правовий статус має включати як права, обов'язки, повноваження, через які вони реалізують норми права, так і юридичну відповідальність як засіб припинення та виховання в дусі додержання закону у сфері відносин, яку вона охоплює.

На наш погляд, адміністративно-правовий статус органів, які забезпечують виконання судових рішень, складається з певних елементів, що становлять основний блок (мету, завдання, принципи органу з примусового виконання судових рішень); організаційно-структурний блок (створення органу, регулювання порядку діяльності, підпорядкованості структурних підрозділів, особливостей діяльності органу з виконання судових рішень); компетеційний блок (права, обов'язки, відповідальність органів у сфері примусового виконання судових рішень). Ми дотримуємося також і наукового погляду В. Авер'янова, на думку якого адміністративно-правовий статус складається з трьох блоків: цільового, структурно-організаційного та компетеційного [5, с. 255].

Утім, незважаючи на всю важливість виконання судового рішення та статусу органів, уповноважених на виконання цих функцій, конституційні положення про забезпечення виконання судового рішення й дотепер належним чином не мають дієвого механізму виконання у вітчизняному законодавстві, нерідко обмежуються, а то й просто порушуються.

Варто звернути увагу на те, що адміністративно-правовий статус органів та осіб, які здійснюють примусове виконання судових рішень і рішень інших органів, має складну нормативно-правову конструкцію, що включає низку елементів: мету створення органу та його завдання; принципи і юрисдикцію діяльності; завдання й функції, що виконує орган; обсяг і характер державно-владних повноважень; форми й методи діяльності; юридичні права й обов'язки; відповідальність суб'єкта владних повноважень у зв'язку з виконанням ним своїх обов'язків.

Перейдемо до аналізу основних суб'єктів (органів), які уповноважені здійснювати відповідні функції у сфері примусового виконання рішень суду, зокрема в частині визначення переліку осіб, що мають право реалізації виконавчого провадження за рішенням суду.

Відповідно до ст. 1 Закону України «Про органи та осіб, які здійснюють примусове виконання судових рішень і рішень інших органів», примусове виконання судових рішень і рішень інших органів (посадових осіб) покладається на органи державної виконавчої служби та приватних виконавців [2]. Згідно зі ст. 6 цього ж нормативного акта, систему органів примусового виконання рішень становлять Міністерство 
юстиції України, органи державної виконавчої служби, створені Міністерством юстиції України в установленому законодавством порядку, а в ст. 7 закріплюється перелік посад державних виконавців [2].

Також у ст. 6 цього ж Закону закріплюється, що виконання рішень можуть здійснюватися іншими органами й установами у випадках, передбачених законом, зокрема рішення щодо стягнення майна та коштів виконуються органами доходів і зборів, а рішення щодо стягнення коштів - банками й іншими фінансовими установами; рішення про стягнення коштів з державних органів, державного та місцевих бюджетів або бюджетних установ виконуються органами, що здійснюють казначейське обслуговування бюджетних коштів [2]. Проте, згідно з п. 4 вказаної статті, зазначені вище органи й установи не $\epsilon$ органами примусового виконання [2].

Нині, на відміну від чинного раніше законодавства, чіткого, законодавчо закріпленого переліку органів виконавчої служби немає. Так, у ст. 3 чинного раніше Закону України «Про державну виконавчу службу» від 24.03.1998 № 202/98-ВР чітко закріплювалося, що до органів державної служби належать: 1) Департамент державної виконавчої служби Мін'юсту України, до складу якого входить відділ примусового виконання рішень; 2) управління державної виконавчої служби Головного управління міністерства юстиції України в Автономній Республіці Крим, головних управлінь юстиції Міністерства юстиції України в Автономній Республіці Крим, головних управлінь юстиції в областях, містах Києві та Севастополі, до складу яких входять відділи примусового виконання рішень; 3) районні, районні у містах, міські (міст обласного значення), міськрайонні відділи державної виконавчої служби відповідних управлінь юстиції [6]. Сьогодні зазначений нормативний акт утратив чинність через прийняття Закону України «Про органи та осіб, які здійснюють примусове виконання судових рішень і рішень інших органів», у якому переліку органів державної виконавчої служби не міститься. Визначити, які ж саме органи належать до органів державної виконавчої служби, можна лише шляхом аналізу підзаконних нормативно-правових актів:
Інструкції з організації примусового виконання рішень, затвердженої Наказом Мін'юсту України від 02.04.2012 № 512/5 (далі - Інструкція з організації примусового виконання рішень) [7], Типового положення про управління державної виконавчої служби головних територіальних управлінь юстиції Мін'юсту України в Автономній Республіці Крим, в областях, містах Києві та Севастополі й Типового положення про відділ державної виконавчої служби головних територіальних управлінь юстиції Мін'юсту України в Автономній Республіці Крим, в областях, містах Києві та Севастополі, затверджених Наказом Мін'юсту України від 20.04.2016 № $1183 / 5$ [8]. Так, відповідно до п. 3 Інструкції з організації примусового виконання рішень, органами державної виконавчої служби $є$ Департамент державної виконавчої служби Мін'юсту України, до якого входить відділ примусового виконання рішень; управління державної виконавчої служби головних територіальних управлінь юстиції Мін'юсту України в Автономній Республіці Крим, областях, містах Києві та Севастополі, до складу яких входять відділи примусового виконання рішень; районні, районні в містах, міські (міст обласного значення), міськрайонні, міжрайонні відділи державної виконавчої служби відповідних територіальних управлінь юстиції [7].

Таким чином, до органів, що здійснюють примусове виконання рішень суду й інших органів, належать Мін'юст України, органи державної виконавчої служби (Департамент державної виконавчої служби Мін'юсту України, управління державної виконавчої служби головних територіальних управлінь юстиції Мін'юсту України в Автономній Республіці Крим, в областях, містах Києві та Севастополі та відділи державної виконавчої служби головних територіальних управлінь юстиції Мін'юсту України в Автономній Республіці Крим, в областях, містах Києві та Севастополі).

Відповідно до ст. 10 Закону України «Про органи та осіб, які здійснюють примусове виконання судових рішень і рішень інших органів», державним виконавцем може бути громадянин України. Крім того, ст. 18 передбачено, що приватним виконавцем також може бути лише громадянин 
України. Таким чином, загальною вимогою, яка висувається до особи як державного, так і приватного виконавця, $\epsilon$ набуття ними громадянства України. Згідно зі ст. 1 Закону України «Про громадянство України» від 18.01.2001 № 2235-III, громадянами України можуть бути особи, які набули громадянства України в порядку, передбаченому законами України й міжнародними договорами України [9]. Громадянство $\epsilon$ основою правового статусу й визначає постійний політико-правовий зв'язок особи та держави, унаслідок чого на особу поширюються суверенні права держави й забезпечується захист ії̈ прав і законних інтересів [10, с. 26]. Як державні, так і приватні виконавці представляють державу у відносинах із примусового виконання судових рішень і рішень інших органів, вони повинні бути громадянами держави, яку вони представляють, а отже, подібна вимога $\epsilon$ цілком правомірною.

Наступною вимогою, що пред'являється до осіб державного і приватного виконавця, $€$ вимога мати юридичну освіту не нижче 2-го рівня (ст. ст. 10, 18 Закону України «Про органи та осіб, які здійснюють примусове виконання судових рішень і рішень інших органів») [2].

Відповідно до Закону України «Про вищу освіту» від 01.07.2014 № 1556-VII, другим рівнем вищої освіти $\epsilon$ магістерський рівень, який відповідає восьмому рівню Національної рамки кваліфікацій і передбачає здобуття особою поглиблених теоретичних i/або практичних знань, умінь, навичок за обраною спеціальністю (чи спеціалізацією), загальних засад методології наукової та/або професійної діяльності, інших компетентностей, достатніх для ефективного виконання завдань інноваційного характеру відповідного рівня професійної діяльності [11].

Таким чином, державними та приватними виконавцями можуть бути особи, що здобули вищу юридичну освіту за ступенем «магістр». Водночас постає питання щодо того, що вважати «юридичною освітою» для визначення вимог до приватних і державних виконавців, оскільки в нормативній і доктринальній площині в Україні із цього приводу немає однозначної думки
Ще однією вимогою, що встановлюється законодавцем до особи державного виконавця, $\epsilon$ здатність за своїми особистими й діловими якостями здійснювати повноваження державного виконавця. Не можна не звернути увагу на певну неоднозначність зазначеного критерію, оскільки важко визначити, які саме особисті й ділові якості можуть обумовити компетентність особи державного службовця. Більш детально такі вимоги конкретизуються в «Спеціальних вимогах до рівня професійної компетентності державних виконавців та керівників органів державної виконавчої служби», затверджених Наказом Міністерства юстиції України від 21.10.2016 № 3005/5 [12], «Спеціальних вимогах до осіб, які претендують на зайняття посад державних виконавців територіальних органів державної виконавчої служби» від 07.11.2016 № 3005/5 [12], «Спеціальних вимогах до осіб, які претендують на зайняття посад державних виконавців відділу примусового виконання рішень Департаменту державної виконавчої служби Міністерства юстиції України», затверджених Наказом Міністерства юстиції України від 21.10.2016 № 3005/5 [13].

Згідно з указаними нормативними актами, державні виконавці повинні володіти такими особистими та діловими якостями, як знання законодавства у сфері виконавчого провадження, професійні знання, лідерство; здатність до прийняття ефективних рішень; комунікативність, особистісна компетенція, здатність приймати зміни та змінюватися, технічні вміння.

На думку Д. Вонна, I. Зарецької, С. Сученка й інших, перевірка особистих і ділових якостей на посаду кандидата державного службовця має суто формальний характер, оскільки неможливо підтвердити документами лідерство, здатність до прийняття ефективних рішень тощо [14, с. 22]. Дійсно, жоден документ не може підтвердити аналітичні здібності, сумлінність, стресостійкість, але зазначені риси можуть бути визначені іншими особами й викладені в характеристиці.

Вимог щодо високих особистих і ділових якостей до осіб приватних виконавців законодавець не встановлює, що $\epsilon$ суттєвою прогалиною сучасного законодавства. Запровадження інституту 
приватного виконавця в Україні пройшло тривалий шлях, аргументи, що обґрунтовують компетентність державних виконавців порівняно з приватними виконавцями, $\epsilon$ встановленими відповідно до вимог законодавства, однак проблемні аспекти $є$ відкритими й потребують удосконалення.

Висновки. Провівши дослідження, проаналізувавши окремі аспекти адміністративно-правового статусу органів та осіб, уповноважених на виконання судових рішень, ми дійшли таких висновків:

1. Окреслені правовідносини, що виникають у частині виконання судових рішень, відбуваються між органами державної влади, які реалізують державну політику у цій сфері з боку фізичних і юридичних осіб, що ухиляються від виконання рішення суду.

2. Адміністративно-правовий статус і діяльність органів та осіб, уповноважених на виконання судових рішень, вимагають поступового перегляду законодавчої бази для визначення регуляторних і наглядових функцій держави.

3. Загальними вимогами, яка висуваються до особи як державного, так і приватного виконавця, $\epsilon$ громадянство України; вища юридична освіта за ступенем «магістр»; здатність за своїми особистими й діловими якостями здійснювати повноваження державного виконавця.

\section{ЛITЕРАТУРА:}

1. Авторгов А.М. Адміністративно-правовий статус державного виконавця : автореф. дис. ... канд. юрид. наук : 12.00.07. Київ, 2008. 19 с.

2. Про органи та осіб, які здійснюють примусове виконання судових рішень і рішень інших органів : Закон України від 02.06.2016 № 1403-VIII. Відомості Верховної Ради України. 2016. № 30. Ст. 542.

3. Коломоець Т.О. Адміністративне право України. Академічний курс : підручник. Київ : Юрінком Інтер, 2011. 576 с.

4. Якімов О.Ю., Овсянко Д.М. Адміністративне право : підручник. Київ : Юрінком Інтер, 2014. 539 с.

5. Виконавча влада і адміністративне право / за загальною редакцією В.Б. Авер'янова. Київ : Видавничий дім «Ін-Ю-ре», 2002. 668 с.

6. Про виконавче провадження : Закон України від 24.03.1998 № 202/98-ВР. Відомості Верховної Ради України. 2016. № 30. Ст. 542.

7. Інструкція з організації примусового виконання рішень : Наказ Міністерства юстиції України від 02.04.2012 № 512/5. Офіційний вісник України. 2012. № 27. С. 23. Ст. 1018.

8. Типове положення про управління державної виконавчої служби головних територіальних управлінь юстиції Міністерства юстиції України в Автономній Республіці Крим, в областях, містах Києві та Севастополі, Типового положення про відділ державної виконавчої служби головних територіальних управлінь юстиції Міністерства юстиції України в Автономній Республіці Крим, в областях, містах Києві та Севастополі : Наказ Мін'юсту України від 20.04.2016 № 1183/5. URL: http://zakon3.rada.gov.ua/laws/show/z0617-16/paran9\#n9.

9. Про гарантії держави щодо виконання судових рішень : Закон України від 05.06.2012 № 4901-VI. Відомості Верховної Ради України. 2013. № 17. Ст. 158.

10. Правові аспекти громадянства в Україні / О.Г. Колб, В.А. Ходирєв, І.Я. Бондар та ін. Луцьк, 2000. 105 с.

11. Про вищу освіту : Закон України від 01.07.2014 № 1556-VII. URL: http:// zakon3.rada.gov.ua/laws/show/1556-18.

12. Спеціальні вимоги до рівня професійної компетентності державних виконавців та керівників органів державної виконавчої служби : Наказ Міністерства юстиції України від 21.10.2016 № 3005/5. URL: http://zakon3.rada.gov.ua/laws/show/z1444-16/paran4\#n4.

13. Самілік Л.О., Розмаїта В.В. Впровадження інституту приватного виконавця в Україні: позитивні та негативні аспекти. Право і суспільство. 2017. № 2. Ч. 2. С. 72-77.

14. Європейські та міжнародні стандарти у сфері судочинства. URL: https://vkksu.gov.ua/ userfiles/doc/perelik-dokumentiv/EU_Standarts_book_web1.pdf. 